(Житомирський національний агроекологічний університет) Lightning25960@gmail.com ORCID: 0000-0002-5468-0078

М. В. Мороз,

старший викладач

(Житомирський національний агроекологічний університет) moros.m.w@gmail.com

ORCID: 0000-0002-9557-9275

\title{
ВИКОРИСТАННЯ АВТЕНТИЧНИХ ВІДЕОМАТЕРІАЛІВ НА ПРОФЕСІЙНУ ТЕМАТИКУ НА ЗАНЯТТЯХ 3 ІНОЗЕМНОЇ МОВИ ДЛЯ СТУДЕНТІВ СПЕЦІАЛЬНОСТІ "ТУРИЗМ"
}

У статті обтрунтовано необхідність удосконалення змісту курсу іноземної мови для студентів спеціальності "Туризм" з метою оптимізації професійної підготовки. Визначено можливості використання автентичних спеціалізованих відеоматеріалів на заняттях з іноземної мови. Розглянуто особливості опрацювання відеоматеріалів конференцій, виставок, семінарів, презентацій та рекламно-

інформаційних матеріалів іноземною мовою. Удосконалено алгоритм роботи з відеоматеріалами, зокрема, впроваджено завдання на опращювання відеоряду.

Ключові слова: спеціалізовані професійні відеоматеріали, завдання на опрацювання відеоряду, професійна підготовка спеціалістів галузі "Туризм".

Постановка проблеми в загальному вигляді та ї̈ зв'язок із важливими науковими і практичними завданнями. Туристична галузь $\epsilon$ надзвичайно перспективним, проте недостатньо розвиненим напрямом економічного розвитку України. Незважаючи на проведення заходів світового рівня впродовж останніх кроків, серед яких фінал чемпіонату Свро 2012, конкурс Свробачення тощо, які відкрили сучасну Україну для багатьох туристів світу, заступник голови Мінекономрозвитку України Михайло Титарчук в інтерв'ю від 22 червня зазначив, що "... в Україні немає жодного туристичного проекту, який відповідає міжнародним стандартам" [1].

3 огляду на вищезазначене актуальним є питання підготовки фахівців галузі туризму, які не лише володіють іноземною мовою на професійному рівні, проте й здатні організувати роботу галузі відповідно до міжнародних вимог, з урахуванням сучасних потреб іноземних туристів.

3 цією метою ми пропонуємо зміцнити міжпредметні зв'язки між професійно-орієнтованими дисциплінами та курсом іноземної мови у вищих навчальних закладах, які готують спеціалістів туристичної галузі, шляхом оптимізації змісту навчального процесу, зокрема, впровадження автентичних відеоматеріалів провідних інформаційних майданчиків світу для професіоналів сфери туризму.

Аналіз основних досліджень i публікацій із зазначеної проблеми. Питанням професійної підготовки менеджерів туризму присвячені роботи Герасимчук Л. В., Лоїк Г. Б., Гарбар Г. А., Полковнікової І. В. тощо. Професійна діяльність спеціалістів будь-якого напряму широко висвітлена у спеціалізованих виданнях та в мережі Інтернет. Професіонали отримують актуальну інформацію на конференціях, зустрічах, виставках, переглядаючи телевізійні програми та новини. У такій галузі, як міжнародний туризм, тримати руку на пульсі подій є невід'ємною складовою успішної професійної діяльності. 3 точки зору перспектив, для застосування на семінарах з іноземної мови відеоматеріали, які відображають зміст вищезазначених подій, є більш перспективними, ніж друковані або електронні джерела, оскільки містять не лише мовленнєву, але й візуальну інформацію, яка допомагає не тільки зрозуміти мовний матеріал, проте й на власні очі побачити реалізацію міжнародних стандартів діяльності в сфері туризму, про які йшлося вище.

Окреслення невирішених питань. Недостатньо вивченим залишається питання інтеграції автентичних професійних відеоматеріалів у зміст курсу іноземної мови для майбутніх спеціалістів туристичної галузі внаслідок низького рівня іншомовної підготовки абітурієнтів, недостатньої кількості навчального навантаження курсу іноземної мови, високого рівня лінгвістичної складності професійноорієнтованих автентичних матеріалів та відсутністю єдиного алгоритму інтеграції матеріалів вищезазначеного характеру до змісту курсу іноземної мови у ВНЗ.

Формулювання мети та завдань статті. Метою цієї статті $\epsilon$ визначення змісту, видів та особливостей роботи із спеціалізованими відеоматеріалами, доступними в мережі Інтернет для професіоналів туристичної галузі. 3 цією метою необхідно вирішити серію завдань: розробити класифікацію існуючих відеоматеріалів англійською мовою, розроблених для професіоналів туристичної галузі, які не потребують адаптації; розробити алгоритм роботи з відповідними матеріалами на заняттях 3 іноземної мови; запропонувати серію завдань для опрацювання відеоматеріалів студентами. 
Виклад основного матеріалу. Переглянувши великий масив спеціалізованих відеоматеріалів, доступних в мережі Інтернет, ми розробили таку їх класифікацію на допомогу викладачу іноземної мови:

За вартістю доступу:

платні: до них належать програми на платному інтернет-телебаченні, певні вебінари, тренінги, навчальні відеоматеріали для туристичних агентів, туристичних операторів тощо.

- безкоштовні: всі матеріали мережі YouTube $є$ безкоштовними. До безкоштовних матеріалів належать виступи на конференціях, презентації, звіти про спеціалізовані виставки, рекламноінформаційні матеріали туристичних агенцій та туроператорів, відео презентації міст та маршрутів, телевізійні програми та новини.

Ми рекомендуємо користуватися безкоштовними матеріалами, оскільки вони не поступаються якістю та змістом. Єдина відмінність полягає в актуальності, адже в надзвичайно динамічному середовищі туризму деяка інформація може виявитися застарілою через тиждень після ії оприлюднення. Проте для навчальних цілей викладачу потрібна не актуальна інформація, а якісна мовна та візуальна інформація, яка є достатньою в безкоштовних відеоматеріалах.

За підходом до розробки змісту ми виділяємо такі матеріали:

- творчий продукт;

- звіти;

- новини.

Новини в галузі туризму можуть висвітлювати інформацію про нові туристичні маршрути та напрями, про міжнародні конфлікти, які впливають на потік туристів або можуть загрожувати їхній безпеці тощо.

У відеозвітах відображаються ключові моменти або презентації семінарів, вебінарів, виставок конференцій, самітів, зустрічей.

До творчих продуктів належить широкий діапазон рекламно-інформаційних матеріалів: відео презентації міст, країн, окремих туристичних об'єктів; реклама туроператорів, туристичних агенцій, турів тощо; телевізійні програми та відео користувачів каналу YouTube, які подорожують та опрацьовують матеріали для оприлюднення для широкого загалу.

При виборі відеоматеріалів викладач має враховувати такі аспекти:

тривалість відео. У мережі ҮouТube доступні відео тривалістю від 5 хвилин до кількох годин залежно від мети та рівня заходу. Наприклад, саміти, міжнародні конференції висвітлюються детально, проте такі відео не є корисними в навчальних цілях (див. наступний пункт).

- Співвідношення цінної інформації та тривалості відео. Відеоматеріал має бути насиченим як 3 огляду на мовну, так і візуальну інформацію. Тривалі речі спікерів на міжнародних виставках та конференціях із туризму, довгі вступи, побічна інформація про прибуття учасників тощо відволікають від засвоєння матеріалу. Доцільно зосереджуватися на промовах окремих спікерів або на коротких відео.

- Якість запису, акцент. Оскільки в галузі туризму залучені професіонали 3 різних країн, необхідно враховувати якість запису та акценти. Проте ми не радимо обмежуватися американськими та британськими матеріалами (для курсу англійської мови) або німецькими (для курсу німецької мови), адже майбутнім спеціалістам туристичної галузі доведеться спілкуватися 3 представниками різних національностей.

Наявність текстового супроводу. Доцільно підбирати відеоматеріали, які мають текстові підказки - презентації конференцій, рекламно-інформаційні матеріали, туристичні гіди по містах світу тощо. Такий текстовий супровід не лише сприяє кращому сприйманню матеріалу, проте й $є$ перспективним навчальним матеріалом.

Навчальний потенціал відеоряду. Вище в цій статті було зазначено про невідповідність туристичної галузі України міжнародним стандартам. Проте вивчення документації щодо міжнародних стандартів не $є$ достатнім для успішної професійної діяльності майбутніх спеціалістів. Візуальна інформація відео з конференцій, виставок та презентацій дозволить студентам на власні очі побачити реалізацію міжнародних стандартів організації відповідних заходів. Тому при розробці завдань на підготовку до перегляду, вправ під час та після перегляду ми радимо структурувати їх за двома напрямами: мова та візуальний ряд.

Складність монтажу. 3 огляду на те, що всі наявні відеоматеріали є продуктом роботи професіоналів у галузі туризму, доцільно на заключному етапі опрацювання відео виконати творче завдання на створення аналогічного продукту. Прості відео 3 нескладним монтажем 3 більшою вірогідністю мотивуватимуть студентів до виконання такого завдання. При цьому завдання може полягати не тільки в знятті аналогічного відео про власне місто або певну місцину, подію тощо, але й у розробці мальованого відеоряду або текстового супроводу, знятті окремого інтерв'ю, складанні презентації тощо. 
3 огляду на вищезазначені критерії, незважаючи на доступність, різноманітність та багатий вибір відеоматеріалів, серед них важко знайти матеріали, які мають навчальний потенціал. Тому ми склали орієнтовний перелік джерел та ресурсів на допомогу викладачам англійської та німецької мови:

- Конференції:

○ Конференції

Ради

туристичної

галузі

http://satic.com.au/index.php/events/conference/;

○ Конференції World

Travel

Market:

https://www.youtube.com/channel/UC3ERBQX_4V809KIpfLes8Pg (англійською мовою);

○ Конференції ITB Berlin: https://www.youtube.com/watch?v=BG85q5-lhFE (англійською та німецькою мовами);

- Презентації міст та маршрутів:

○ Канал Expedia: https://www.youtube.com/watch?v=vzSHcyXfNPw (англійською мовою);

○ Канал http://www.ardmediathek.de/tv/reise;

○ Канал Deutschland.de: https://www.youtube.com/user/magazinedeutschland/videos (німецькою мовою);

- Міжнародні спеціалізовані виставки:

- Arabian

Travel

Market:

https://www.youtube.com/playlist?list=PLDRLTlqgJFAueo5Gw2LVltDf4VrbB58ZJ (англійською мовою);

○ Щорічна міжнародна виставка ITB Berlin (http://www.itb-berlin.de/de/Aussteller/SpeedDating/;

- GTM Germany Travel Mart: http:/www.germany.travel/de/trade/gtm-germany-travel-mart/gtmreportagen/live-reportage.html (німецькою мовою);

- Рекламно-інформаційні матеріали, новини, випуски блогерів:

○ Презентації туристичних компаній, які брали участь у Міжнародній спеціалізованій виставці WTM у 2017 році: http://london.wtm.com/en/exhibitor-directory-2017/Presentations/\#;

- Матеріали, оприлюднені Свропейською асоціацією туризму: https://www.youtube.com/user/ETOALtd/videos;

○ Відео, оприлюднені на каналі "New York Habitat", в цікавому та динамічному форматі від імені блогера представляють різні міста світу за кілька хвилин: https://www.youtube.com/user/NewYorkHabitat;

○ Відео 3 корисними та актуальними, нетрадиційними порадами для подорожуючих: https://www.youtube.com/user/NewYorkHabitat (англійською мовою);

○ Канал Deutschland.de: https://www.youtube.com/user/magazinedeutschland/videos;

- Відеоматеріали інтернет-ресурсу Frankfurter

http://www.faz.net/aktuell/reise/deutschland-die-101-wichtigsten-deutschen-orte-13526987.html

Allgemeine: мовою).

Розглянемо традиційний алгоритм роботи з відеоматеріалами на заняттях із іноземної мови 3 метою визначити, яким чином застосовувати відеоряд з метою професійного розвитку студентів. По-перше, слід зазначити, що не всі науковці приділяють достатньо уваги опрацюванню відео на заняттях з іноземної мови. Так, традиційно визначають особливості та виділяють етапи роботи 3 друкованим текстом та аудіоматеріалами. Зокрема, недостатньо уваги приділено особливостям роботи 3 відеоматеріалами і в грунтовних роботах таких передових науковців як Соловова Є.Н., Гальскова Н.Д., Гез Н.І., Колкер Я.М. тощо. Дмитренко Т.А., Маслико Є.А., Бабінська П.К., Будько А.Ф., Петрова С.I., Попов А.І. проводять аналогію між роботою над аудіюванням та відео, яка включає три етапи: переддемонстраційний, демонстраційний та післядемонстраційний, які здебільшого повторюють методику роботи над розвитком навичок та умінь аудіювання.

На першому, дотекстовому, етапі (також "переддемонстраційний", "before listening") студенти готуються до сприймання аудіо (відео) тексту. Усуваються можливі мовні труднощі (студенти ознайомлюються 3 новою лексикою, повторюють граматичні форми тощо), виконуються вправи на антиципацію та предикцію в трьох аспектах: мова, зміст та соціокультурні особливості. Надається установка на перегляд.

На другому, демонстраційному (також "while listening / watching") етапі студенти виконують завдання безпосередньо під час демонстрації відео, і такі завдання також мають передбачати опрацювання власне змісту, а також мовного та соціокультурного матеріалу.

Не третьому, післядемонстраційному, етапі (також "післятекстовий" або "after listening") студенти перевіряють завдання попередніх етапів, після чого виконуються завдання на розвиток вмінь та навичок монологічного, діалогічного мовлення та письма [2: 136].

Таким чином, навчальний процес зосереджено на лінгвістичному та соціокультурному матеріалі, а навчальний потенціал відеоряду 3 огляду на професійний розвиток здебільшого ігнорується. Тому надзвичайно цікавим є завдання розробки системи вправ на опрацювання відеоряду робочих матеріалів, створених для професіоналів туристичної галузі, зокрема, зосередившись на навчальних потребах українських студентів. 
Такі навчальні потреби полягають у розвитку та набутті знань та умінь, необхідних для формування та розвитку туристичної інфраструктури, залучення іноземних туристів на рівні, адекватному потенціалу нашої країни.

Серед факторів, які майбутні спеціалісти матимуть подолати, або які мають враховувати як негативні чинники в своїй професійній діяльності, зокрема, виділяють такі:

- Мережа та об'єкти туристичної інфраструктури не відповідають світовим стандартам і $є$ недостатньо розвиненими;

- Нерезультативні дії з просування туристичного продукту на міжнародному ринку; неякісна реклама вітчизняних курортів;

- Недостатньо розвинені сучасні туристичні технології, зокрема, відсутні або неякісні електронні інформаційні довідники, де міститься інформація про готелі, маршрути та туристичні агенції;

- Недостатньо кваліфіковані працівники туристичної галузі, що призводить до низького рівня обслуговування [3: 447].

Саме від професійно-орієнтованого навчання майбутніх представників туристичної галузі залежить подолання вищезазначених внутрішніх факторів, які спричинюють низький попит міжнародних туристів на продукт вітчизняної туристичної галузі. Студенти спеціальності "Туризм" мають володіти іноземною мовою на достатньо високому рівні, щоб вивчати, оцінювати, аналізувати та впроваджувати досвід іноземних постачальників туристичних послуг на українському ринку. Тому система завдань на вивчення відеоряду відео продуктів туристичної галузі має бути включена до алгоритму опрацювання відео на рівні мовного матеріалу.

Наведемо перелік вправ та завдань, які доцільно використовувати на кожному етапі роботи 3 відеоматеріалами на заняттях 3 іноземної мови у немовному ВНЗ під час підготовки студентів спеціальності "Туризм".

До перегляду відео з туристичної конференції, саміту, виставки:

- $\quad$ Назвіть три технічних засоби, які ви очікуєте побачити.

- $\quad$ В двох стовпчиках ви бачите (a) розклад та (б) події виставки. Розташуйте події за розкладом.

- 3 огляду на назву конференції, які три твердження з п'яти, наведених нижче, ви очікуєте почути.

До перегляду презентацій міст та маршрутів:

- Які відомі місця ви очікуєте побачити? (підказки - текстові, фото тощо).

- Які ресурси необхідні для зняття відео презентації міста?

- Скориставшись переплутаними підказками, відтворіть план відео.

До перегляду рекламно-інформаційних матеріалів, новин, відео блогерів:

- $\quad$ Перегляньте перелік ключових фраз та спрогнозуйте, про що йдеться у відео.

- Перегляньте фото та відгадайте, про яке місто / країну йтиметься у відео.

- Правильні / неправильні твердження тощо.

Під час перегляду відео з туристичної конференції, саміту, виставки:

- Дайте відповідь на питання.

- Заповніть план конференції.

- Складіть план приміщення (де розташовуються гості, спікери, ведучий тощо).

- Складіть перелік технічних засобів, які використовуються під час конференції.

- Складіть план відео звіту про конференцію.

Під час перегляду презентацій міст та маршрутів:

- Складіть план відео.

- Дайте відповідь на низку питань.

- Перегляньте відео без звуку, розташуйте текстові підказки за чергою демонстрації на відео.

Під час перегляду рекламно-інформаційних матеріалів, новин, відео блогерів:

- Дайте відповідь на питання.

- Правильні / неправильні твердження.

- Підніміть руку, коли побачите на відео такі предмети / людей / будівлі...

- Переглядаючи відео, складіть перелік засобів, необхідних для його зйомки.

Після перегляду відео з туристичної конференції, саміту, виставки:

- Заплануйте конференцію в своєму місті (місце проведення, гості, спікери, ведучий, кількість запрошених, розташування гостей тощо).

- Складіть бюджет проведення подібної виставки у вашому місті.

- Програйте діалог із потенційним спікером, запрошуючи його на конференцію.

- Складіть маршрут, щоб гості вашої конференції могли дістатися до місця ії проведення (з готелю, автовокзалу, з/д вокзалу, на авто тощо).

Після перегляду презентацій міст та маршрутів:

- Розробіть аналогічний відеоряд (можливо із фото або малюнків) для презентації власного міста. 
- Запишіть відео діалогу із мешканцем вашого міста про найцікавіші місця для туристів, накладіть текстовий супровід.

Розробіть текст для презентації вашого улюбленого маршруту.

Після перегляду рекламно-інформаційних матеріалів, новин, відео блогерів:

- Складіть матеріали для рекламно-інформаційного стенду вашого міста.

- $\quad$ Зніміть селфі походу вашим містом із англомовним коментарем за прикладом відомого блогера тощо.

Висновки та перспективи подальшого дослідження. Іншомовні відеоматеріали можуть використовуватися під час підготовки студентів до професійної діяльності в галузі туризму не лише 3 метою навчання іноземної мови, але й як ресурс для занурення студентів у реальний світ міжнародного туризму, ознайомлення студентів із усіма аспектами роботи туристичних агентів, операторів, галузевих спеціалістів, для чого доцільно застосовувати запропоновану в статті систему завдань та вправ на опрацювання відеоряду автентичних професійних матеріалів.

\section{СПИСОК ВИКОРИСТАНИХ ДЖЕРЕЛ ТА ЛІТЕРАТУРИ}

1. Титарчук М. Михайло Титарчук: "В Україні немає жодного туристичного проекту, який відповідає міжнародним стандартам" : [інтерв'ю з Заступником голови Мінекономрозвитку Михайлом Титарчуком від 22 червня 2017 року] [Електронний ресурс] / за матеріалами ТСН. - 2017. - Режим доступу : https://tsn.ua/interview/v-ukrayini-duzhe-bagato-proektiv-ale-zhodnogo-yakiy-vidpovidav-bi-mizhnarodnimstandartam-949788.html.

2. Соловова Е. Н. Методика обучения иностранным языкам : Базовый курс лекций : [пособие для студентов пед. вузов и учителей] / Е. Н. Соловова. - М. : Просвещение, 2002. - 239 с.

3. Цюпак М. І. Статистичний аналіз діяльності підприємств туристичної та готельної індустрії / М. І. Цюпак // Економічні науки. Серія "Облік і фінанси". Збірник наукових праць. Луцький національний технічний університет. Випуск 7 (25) - Ч. 3 - Редкол. : відп. ред. д.е.н., професор Герасимчук 3. В. - Луцьк, 2010. C. $440-449$.

\section{REFERENCES (TRANSLATED \& TRANSLITERATED)}

1. Tytarchuk M. Mykhailo Tytarchuk: v Ukraini nemaie zhodnogo turystychnogo proektu, yakyi vidpovidaie mizhnarodnym standartam : [interviu z zastupnykom golovy Minekonomrozvytku Mykhailom Tytarchukom vid 22 chervnia 2017 roku] [Mykhailo Tytarchuk : "There is No Project in the Sphere of Tourism in Ukraine That Complies with the International Standards : [An Interview with Mykhailo Tytarchuk, Deputy Head of the Ministry of Economic Development, June 22 $\left.{ }^{\text {nd }}, 2017\right]$. - Rezhym dostupu : https://tsn.ua/interview/v-ukrayini-duzhe-bagatoproektiv-ale-zhodnogo-yakiy-vidpovidav-bi-mizhnarodnim-standartam-949788.html (accessed 20 October 2017).

2. Solovova Ye. N. Metodika obucheniia inostrannym yazykam : bazovyi kurs lektsii : [posobiie dlia studentov ped. vuzov i uchitelei] [Methodology of Teaching Foreign Languages: Basic Lecture Course] / Ye. N. Solovova. - M. : Prosvieshcheniie, Moscow. -239 p.

3. Tsiupak M. I. Statystychnyi analiz diialnosti pidpryiemstv turystychnoi ta gotelnoi industrii [The Statistical Analysis of Tourism and Hotel Industry Businesses / M. I. Tsiupak Ekonomichni nauky. Seriia "Oblik i finansy" [Economics. "Accounting and Finances" Series], in Herasymchuk Z.V. (Ed.), Proceedings of Lutsk National Technical University. - Vypusk 7 (25). - Ch. 3, Lutsk. - Pp. 440-449.

Ващенко С. В., Мороз М. В. Использование аутентичных видеоматериалов на профессиональную тематику на занятиях по иностранному языку со студентами специальности "Туризм".

В статье обоснована необходимость усовершенствования содержания курса иностранных языков для студентов спеичильности "Туризм" с иелью оптимизации их профессиональной подготовки.

Установлены возможности использования аутентичных специализированных видеоматериалов на занятиях по иностранному языку. Рассмотрены особенности обработки видеоматериалов конференций, выставок, семинаров, презентаций и рекламно-информационных материалов на иностранном языке. Усовершенствован алгоритм работы с видеоматериалами, в частности, внедрены задания на обработку видеоряда.

Ключевье слова: специализированные профессиональные видеоматериаль, задания на обработку видеоряда, профессиональная подготовка специалистов в сфере "Туризм".

\section{Vashchenko S. V., Moroz M. V. Introducing Authentic Professional Video Materials into Foreign Language Teaching Content for Students Specializing in Tourism.}

The article explores the possibilities of interdisciplinary connections between teaching foreign languages and professional development course for future specialists of the tourism industry with the goal of improving the content of language teaching through introducing video materials. Based on extensive study of authentic professional video materials covering professional events in the field of tourism, such as conferences, summits, 
exhibits, presentations, advertising, promotion campaigns and other materials available on the Internet, a classification of the aforementioned videos is developed from the FLT perspective. The materials are further analyzed for their fitness for the purpose of preparing students to solve critical issues of the tourism industry in Ukraine, such as rendering the tourist infrastructure compliant with the international standards; promoting the Ukrainian tourism offers on the global level; efficient exploitation of state-of-the-art technologies used in the sphere of tourism; improving service quality. The article suggests exploiting the storyboard for the aforementioned purpose, along with the traditional approach of focusing on the language component. The algorithm of working with videos in the language classroom is enriched by a suggested set of pre-viewing, whileviewing and post-viewing tasks designed to build the professional mindset and provide stimulus for foreign language communication in the professional domain.

Key words: authentic professional video materials, storyboard tasks, professional development of specialists in the field of tourism. 